\title{
Displaced Iraqis in Jordan: Formal and Informal Information Flows, and Migratory Decisions in a Context of Uncertainty
}

\author{
Adam Saltsman
}

\begin{abstract}
While it is not uncommon for humanitarian organizations, such as the UN High Commissioner for Refugees (UNHCR), to implement information campaigns about forced migrant rights, the assistance available to them, and options for the future, these efforts often meet unintended consequences. Forced migrants have, at times, rejected, misinterpreted, and condemned the information they get from these sources. This paper argues that official information campaigns often falter for two crucial reasons beyond resource scarcity. First, those agencies disseminating information are often under pressure to curb the outflow of migrants from the Global South, and as a result, information provision has tended to be coloured by efforts to control or protect against forced migrants' movement or desires. Second, these agencies do not typically consider or engage with migratory capital, including migrants' informal networks for sharing knowledge about the migratory process. As a case study, this paper relies on qualitative interviews and focus groups with Iraqis displaced in Jordan to explore their lived experiences vis-à-vis both the official information from humanitarian agencies and their informal networks that are transnational in nature.
\end{abstract}

\section{Résumé}

Alors qu'il n'est pas rare que les organisations humanitaires, telles que le Haut Commissariat des Nations Unies pour les réfugiés (UNHCR), mettent en place des campagnes d'information sur les droits des migrants forcés, l'aide accessible et leurs options d'avenir, on constate que ces efforts ont souvent des conséquences inattendues. En effet, ces migrants peuvent à certains moments rejeter, mal interpréter, et condamner l'information qu'on leur donne. Cet article montre que ces campagnes d'information échouent principalement pour deux importantes raisons, qui dépassent de loin le manque de ressources. Premièrement, les agences qui transmettent l'information travaillent souvent sous la pression qu'elles ont de freiner le nombre de migrants de l'hémisphère sud, avec la conséquence que l'information se trouve déformée par l'intention sous-jacente de contrôler les mouvements et désirs des migrants forcés. Deuxièmement, ces agences ne prennent pas en compte le capital migratoire, incluant les réseaux informels des migrants qui se transmettent leur connaissance du processus migratoire. L'étude de cas que constitue cet article se base sur une série d'entrevues qualitatives et de groupes de discussion avec des Irakiens réfugiés en Jordanie, afin d'explorer leurs expériences face, à la fois, à l'information fournie par les agences humanitaires et à celles obtenues à travers leurs réseaux informels et qui sont en soi transnationaux.

\section{Introduction}

In the context of humanitarian intervention, safeguarding the basic human rights of forced migrants requires the dissemination of information about their rights, the assistance available to them, and options for the future. ${ }^{1}$ United Nations bodies, such as the United Nations High Commissioner for Refugees (UNHCR) and the Inter-Agency Standing 
Committee (IASC), recognize "the right to seek, receive and impart information" for all individuals, including forced migrants. ${ }^{2}$ These agencies also promote the widespread dissemination of information because of their regard for human dignity and because they see information sharing as a means to build trust and respect with refugees. "The more information shared with refugees about issues of concern to them," states UNHCR, "the more involved, engaged and empowered they will be."4 Stemming from this position are numerous "information campaigns," where UN agencies charged with providing humanitarian assistance create or support such informational initiatives as radio programs, television spots, cultural performances, education programs, and-perhaps most commonly-posters and leaflets, all with the purpose of informing refugees about available services and options for their future. ${ }^{5}$

Despite such efforts, these agencies transmit little concrete information about temporary or permanent solutions to forced migrants' displacement, and their campaigns lead to unintended consequences in countries of first asylum as forced migrants have, at times, rejected, misinterpreted, and condemned the information they get from international humanitarian agencies. Instead of feeling empowered, forced migrants have felt disenfranchised and objectified, increasingly desperate at the uncertainty of their situation. ${ }^{6}$ Scholars have noted the cyclical nature of mistrust in contexts of displacement; agency staff and forced migrants become more suspicious of one another's intentions as both groups clash over the allocation of limited resources.

This paper argues that official information campaigns often falter for two crucial reasons beyond resource scarcity. First, supra-state agencies charged with the protection and assistance of refugees find themselves torn between this mandate and pressure from state governments to curb the flow of migrants from sending countries, particularly those in the Global South. ${ }^{8}$ As a result, UNHCR has explicitly framed its commitment to information provision as a tool to encourage displaced persons to stay in or return to their home country ${ }^{9}$ and the agency has developed global protocols that reflect a need to protect against the inherent pressure of forced migrants wishing to resettle to the Global North. ${ }^{10}$ Second, agencies typically fail to give attention to migrants' informal networks for sharing knowledge about the migratory process. Far from passively waiting for official word from state or supra-state agencies, forced migrants actively rely on their own networks to comprehend their options, and the knowledge in these networks often contradicts the "official story." This article seeks to address both of these assertions through a case study of Iraqis displaced in Jordan negotiating with state and suprastate bureaucracies, their own insecure circumstances, and their transnational networks of informal information to decide their next step.

The first part of the article argues for consideration of transnational migratory capital, particularly in terms of knowledge construction, as the key for the transmission and reception of crucial information forced migrants use to make decisions about the future. The second part outlines the history of Iraqi displacement in recent decades, followed by a presentation of methods used in this study. The next part explores how respondents experience both official information and the informal knowledge of their transnational networks in a context of vulnerability and insecurity.

\section{Migratory Capital, Information Provision, and Iraqis as Transmigrants}

To date, there is little research about the relation between official information programs and informal networks for the exchange of knowledge in contexts of displacement. Khalid Koser highlights the extent to which information constitutes a key element in forced migrants' decisions about repatriation. Focusing on knowledge communicated informally between refugees, Koser describes a trajectory beginning with the initial displacement when little information is available followed by floods of rumours as the displaced population increases, and, finally, the establishment of durable social and kin-based networks for information exchange. Koser notes that refugees evaluate received information according to fluid notions of the information transmitters' trustworthiness and relevance. ${ }^{11}$ Amy West and Lydia Wambugu show how the tendency of humanitarian and state agencies to limit the quantity and quality of information reaching encamped forced migrants exacerbates the proliferation of informal information networks, which they consider dangerous because of the rumours they circulate. According to West and Wambugu, as one source of information becomes limited, another less reliable one proliferates. Critiquing the UN refugee agency and the government of Tanzania for restricting the flow of important information to forced migrants, they write, "their actions have created a parallel system, forcing refugees to view both as yet another threat to their survival, instead of legitimate guarantors of their security and well-being."12 Such work challenges the notion that migrants are passive; that they do not employ a variety of resources to manage their circumstances. Yet even while focusing on agency among refugees, this work nevertheless depicts the flow of informal information as largely erroneous, misleading, and correlated with formal information.

My study views the informal exchange of information among migrants and between them and both their 
communities of origin and official bodies as migratory capital reproduced and exchanged transnationally. ${ }^{13}$ This formulation leaves open the question of whether official or unofficial sources constitute the most reliable information. Instead, I focus on exploring which information is most consequential for the decision-making process of forced migrants.

Originally considered as "the processes by which immigrants forge and sustain multi-stranded social relations that link together their societies of origin and settlement,"14 transnationalism has, in recent years, called for a deterritorialization of relations across space. ${ }^{15} \mathrm{~A}$ range of factors associated with the contemporary political, social, and economic landscape push and pull relationships beyond nationstate boundaries so that they are flexibly rooted in transnational social fields. ${ }^{16}$ As such, transnational networks are conduits for the global flow of knowledge and resources, both material and virtual, and they lead to the formation of logics that are more transnational than national. ${ }^{17}$

Part of what causes transnational elasticity is the broad impact of supra-state governance structures, economic and political multilateral collectivities intimately connected to the fact that there are currently over 30 million people stateless or displaced ${ }^{18}$ and millions more undocumented migrants whose lives are regulated by entities of global governance as well as authoritarian and liberal democratic states. ${ }^{19}$ Within migrant populations, there are many who are regularly or repeatedly on the move by varying degrees of choice and coercion. ${ }^{20}$ As many migrants in precarious circumstances find themselves "thrown out of the family of nations," 21 repeated displacement over time requires them to depend on and further construct circuits of information, resources, and contacts formed over generations of group migration. ${ }^{22}$ These networks span communities of origin, locales of displacement, and occasionally new communities of long-term settlement. ${ }^{23}$ Forced migrants must rely more completely upon their accumulated collective migratory capital, ${ }^{24}$ that is "knowledge of how to go about migration, how to deal with brokers, traffickers, border officials and bureaucrats, how to develop and maintain contacts in receiving countries, and how to find accommodation, secure social security entitlements or gain employment." 25 Thus, it is important to focus on the ways in which such individuals "find in mobility a resource, not only a constraint"; on the ways in which "an initially imposed dispersion is turned to advantage." ${ }^{26}$ Adopting this perspective, this paper gives attention to the ways in which displaced persons discuss their utilization of the socio-cultural resources they mobilize in response to exile. ${ }^{27}$

Addressing questions of how the regulation of official information relates to the management of the migrant population, Dorothy Smith asserts that institutional knowledge serves as a tool of governance. ${ }^{28}$ Smith distinguishes between two forms of knowledge. First, the knowledge of the local and the particular is knowledge generated through experience. The notion of "local" here is taken to be not necessarily a spatial reference, but rather an exchange between and among individuals and collectivities of experiential accounts. Second, the objectified knowledge of the "extra-local" is that which has been abstracted from lived experience to be useful on an institutional and administrative level. ${ }^{29}$ As such, objectified knowledge subjugates the knowledge of the local and the experienced as irrelevant, chaotic, or even dangerous. To Smith, the governing processes of society construct a knowledge for the purpose of management and control in which "issues are formulated because they are administratively relevant, not because they are significant first in the experience of those who live them." 30 Such processes "eliminate the presence of subjects as agents." 31

In terms of migration, official information consists of the knowledge of migrants' experience objectified through processes of institutional assessment of migrants' claims. These official assessments subject the lived experience of migrants to multiple levels of bureaucratic analysis of criteria for refugee status and resettlement to Global North nationstates. To be deemed a refugee-and one eligible for resettlement-is contingent on the ways in which nation-state and supra-state actors categorize migrants' lived experience on an institutional level. ${ }^{32}$ When Iraqi forced migrants look toward the agencies and organizations regulating resettlement for information, they are in a sense attempting to learn how their lived experiences have been or may be categorized into official knowledge, what this implies for their future and, for those intent on resettling, how they can best account for their lived experience in order to end up categorized as "eligible."

\section{The Context of Iraqi Displacement in Jordan}

Chatelard has written on the establishment and maintenance of networks among Iraqi forced migrants who have experienced multiple waves of displacement. ${ }^{33}$ She refers to Amman and Baghdad as "translocal spaces," in which individuals have moved and continue to move between the two locales to conduct business and politics, attend school, and visit hospitals among other activities. ${ }^{34}$ Iraqis have long included Jordan as a destination for translocality or merely for transit. ${ }^{35}$ Large-scale forced migration has taken place primarily since the mid-1990s in the aftermath of the first Gulf War and subsequent sanctions. ${ }^{36}$ There were believed to be between 250,000 and 350,000 Iraqis in Jordan by 2003. ${ }^{37}$ 
The outpouring over the last seven years of forced migrants from Iraq into neighbouring countries constitutes one of the world's largest humanitarian crises. There are believed to be five million displaced Iraqis, about half of whom fled beyond the borders of their country and a portion of whom were displaced over previous decades. ${ }^{38}$ While the total number of Iraqi forced migrants in Jordan is heavily debated, there are approximately 60,000 registered with UNHCR, ${ }^{39}$ while there are more than 200,000 registered in Syria and an additional 10,000 in Lebanon. ${ }^{40}$ It is believed that tens of thousands more are unregistered in each country. ${ }^{41}$ Beyond these numbers are several thousand more who have used neighbouring countries as places of transit before migrating elsewhere. ${ }^{42}$ For the last four years, Iraqis have constituted the largest group of asylum seekers in industrialized countries. ${ }^{43}$ However, the journey to seek asylum in the European Union and elsewhere is often a dangerous one ending in detention and deportation, directly or ultimately to Iraq. ${ }^{44}$

\section{Jordan as a Vulnerability Context}

Jordan-and the other first countries of asylum-constitutes what has been termed a "vulnerability context," 45 in which host country laws and policies, public and private refugee support networks, and broader public attitudes toward forced migrants lead to particular sets of opportunities and constraints for the refugee communities. In urban settings, such as Amman or Damascus, the vulnerability context is contingent on both forced migrants' legal status and their access to livelihoods. ${ }^{46}$ During a 2009 evaluation, UNHCR determined that the primary constraints for the Iraqi forced migrant population consisted of punishments for violations of immigration policy, refoulement (forced return to a context of persecution), a lack of access to health and education services, limited financial resources/employment, and relations with the host country. ${ }^{47}$ Additional assessments have identified gender as an important variable for determining this population's vulnerability. ${ }^{48}$

The legal rights of Iraqis displaced in Jordan remain highly limited, despite advocacy on their behalf by rightsbased organizations. ${ }^{49}$ Residency and legal employment remain significant challenges. In May 2008, the Jordanian government issued new visa rules requiring Iraqis to obtain Jordanian visas from Iraq before arriving at the border. ${ }^{50}$ Visa and livelihood expenses are difficult to pay for those with dwindling financial resources, especially since the Jordanian government has continued to prohibit the employment of Iraqi forced migrants without residency and work permits. There are many Iraqis in Jordan without residency who work in the informal economy, but they are often subject to poor working conditions, arbitrary dismissal, and deportation by Jordanian security officials. ${ }^{51}$ And while Iraqi school-aged children are now permitted to attend Jordanian public schools and while Iraqis have access to Jordan's health-care system, the difficult financial situation has led to debt, exploitation in the informal economy, and unhealthy living conditions. ${ }^{52}$

A study by Fafo, the Norwegian research centre, found that in 2007 approximately 20 percent of households were female-headed and these were concentrated among the poorer households. Other studies have pointed to increased instances of sexual abuse and exploitation and domestic abuse against women as a result of displacement. ${ }^{53}$ Despite this, Iraqi women have been found to be more resilient than men in first countries of asylum. ${ }^{54}$ Finally, Sassoon highlights that many Jordanians see the influx of Iraqis to be causally related to greater inflation, higher housing prices, and the undercutting of Jordanian wages. This has led to widespread public resentment of the Iraqi forced migrant population. ${ }^{55}$

On the international level, the humanitarian community has responded to this most recent Iraqi refugee crisis by establishing a protection and assistance regime. This comes in the form of cash assistance, the provision of nonfood items, psychosocial counseling, vocational training, community development, refugee status determination, and resettlement. As Iraqis continue to flow in and out of countries of first asylum and as assistance programs grow or shrink according to donor priorities and resources, concerns about the future are increasingly becoming a source of tension and desperation.

\section{Resettlement and the UN's Policy on Information Provision}

Each country of resettlement has its own criteria upon which it relies to screen Iraqis. UNHCR considers these criteria and makes referrals of individual cases to the appropriate countries. Currently the international community considers resettlement the primary viable solution for Iraqi refugees; the governments of neighbouring countries do not permit formal integration into their societies and only relatively small numbers have officially returned to Iraq. ${ }^{56}$ Since 2007, UNHCR has referred approximately 82,000 Iraqi refugees from the region to 17 different countries, including the United States, Canada, Australia, the United Kingdom, and Sweden. ${ }^{57}$ The United States has taken the bulk of those resettled, approximately 19,000 in $2009 .{ }^{58}$

When it comes to decisions about resettlement, UNHCR stresses that the whole process should be "transparent visà-vis refugees." 59 To this end, "information meetings may be held to inform refugees and resettlement partners of the 
standards and procedures governing the resettlement process in a given Field Office." 60

However, UNHCR also stresses the need to manage expectations:

With limited information about the nature and limitations of resettlement as a durable solution, refugees may develop unrealistic expectations about resettlement. Such expectations could potentially result in increased desperation on the part of refugees and excessive pressures on an [UNHCR] Office, and eventually undermine the resettlement process as a whole. ${ }^{61}$

The latter reveals a fundamental paradox in UNHCR's guidelines: their desire to empower and protect the freedoms of refugees is tempered by an awareness that uncontrolled, forced migrants will damage the very resettlement process set up to help them. On some level, protection entails "guarding" refugees from themselves. In this sense, information provision should reduce unrealistic expectations. Thus, there may be certain official knowledge or experiential information about the migratory process that should be kept from migrants, in the name of protecting migrants as well as the staff and mission of UNHCR. For example, state and UN agencies have articulated their need to manage refugee expectations in terms of "shopping," i.e., the search for the asylum or resettlement site with the best resources. ${ }^{62}$ Of course, there may also be some questions from forced migrants to which UNHCR simply does not have the answer. UNHCR and others have noted that they are frequently inundated by phone and in-person queries from Iraqis. ${ }^{63}$ An escalation of requests or demands could make it more difficult for UNHCR to manage the displaced group, given limited resources.

Additionally, while UNHCR resettlement policy states that the refugee or whoever referred her or him to UNHCR "should be notified in writing that the refugee will not be considered for resettlement," 64 when it comes to granting an individual case access to her or his file, UNHCR also notes in an internal document:

UNHCR needs to weigh its own interests (such as staff safety considerations or protection of UNHCR's sources of information) against the [refugee's] legitimate interest, for instance, to know the reasons for any decision that affects her or him.

Such a guideline may be understandable and appropriate; however, in the context of Iraqi displacement, UNHCR's decision to withhold this key information from those Iraqi forced migrants who will not be referred for resettlement has led many within this population to react in unanticipated ways.

\section{Methods}

This article is based on semi-structured interviews and focus groups conducted during the summer of 2009 and spring of 2010 with 25 Iraqis displaced in Jordan, a purposive sample from a larger $n$ of approximately 60 Iraqis who participated in a broader study focused on resettlement and information. This research represents the co-construction of knowledge between researcher and the researched. Given my position as a Global North researcher working in Jordan among displaced populations, participants and I were aware of the vast asymmetry that lay between us. This challenges concepts of consent and threatens to render the interview a reproduction of unequal power relations. ${ }^{65}$ I conducted this fieldwork not only for academic research, but also for an NGO concerned with international policy on resettlement for Iraqi forced migrants; research participants were informed of this dual purpose. As somebody working with an NGO and conducting empirical research, I acknowledge that while negotiating the "activist-scholar divide," my study reflects a dual imperative: my interest in conducting an academically rigorous study and my commitment to action research. ${ }^{66}$

Of the 25 research participants, 13 participated in indepth, open-ended interviews, while 12 participated in focus group discussions. Ten focus group discussions were conducted for the larger study. A slight majority of participants were women (52 percent; $n=13)$. Forty percent $(n=10)$ of the participants were between 18 and 30,56 percent $(n=14)$ were between 30 and 50, and one participant was 64 . All research participants are Iraqi nationals, though they differ in terms of their place of origin; a majority of participants were from Baghdad. Close to 65 percent of participants came from a middle-class socio-economic background with professions like engineer and teacher, while the remainder were from working-class backgrounds and had had jobs in Iraq such as mechanic and vendor. This study did not measure religious or sectarian breakdown among participants for a variety of reasons, ${ }^{67}$ though it is important to note that according to a 2007 survey, 60 percent of the Iraqi households in Jordan are Sunni, 18 percent are Shiite, 15 percent percent are Christian, and 5 percent are those that follow other religious traditions, particularly Sabean and Yedizis. ${ }^{68}$ As a purposive sample, participants were recruited from the community centres and reception rooms at international humanitarian NGOs in Amman and one Jordanian community-based organization located in Baqa'a, a Palestinian refugee camp 20 kilometres outside of Amman. Thus, 20 out of 25 participants came from urban parts of Jordan. ${ }^{69}$ Visiting Jordan several times between June 2009 and July 2010, I was able to recruit respondents in three iterations according to the themes emerging from initial analyses 
of my data, a partial theoretical sample; ${ }^{70}$ partial because iterative recruitment was constrained by my limited visits during which I had to meet the goals of the NGO for which I worked. All the names of respondents have been changed to pseudonyms. Interviews were conducted in Arabic with English interpretation in private within the offices of the organizations where recruitment took place. An interview guide was produced in English, translated into Arabic, and then checked for linguistic equivalence.

In analyzing interview and focus group transcripts, I conducted line-by-line and focused coding to build inductive and interpretive theoretical assertions that stem from my understanding of participants' explanations of lived experiences. ${ }^{71}$ This form of analysis reflects the initial coding stages of a more constructivist version of the grounded theory method upon which I relied in designing and developing this research. Despite this reliance on constructivism in my design and interviewing processes the current research does not include the development of a new theory per se. ${ }^{72}$ I also, less subjectively, analyzed thematic codes to locate respondents' voices within the vulnerability context discussed above in order to highlight how this study's respondents are situated in relation to the literature (see Table 1). ${ }^{73}$ This should not be conflated with respondents' articulation of their perceptions of vulnerability.

\section{Migrant Experiences with Official Information and Local Knowledge}

Initial and focused coding yielded specific analytical themes. Codes clustered around the topics of trust, security, and options for the future in terms of institutional and official sources of information and participants' own reliance on and contribution to local, experiential knowledge. Analysis reveals that migrants' experience with uncertainty, real or perceived insecurity, and their mistrust of the institutions regulating migration are all interconnected. The first part of this section deals with the connection between being in a vulnerability context and the ways in which Iraqis experience official sources of information. Second, I examine how the respondents' ability to rely on networks of experiential knowledge relate to their context and their perception of official information.

\section{Insecurity, Vulnerability, and Experiences with Official Information}

Sixty percent of the research participants who noted a lack of access to information had also experienced a range of difficulties in Jordan from abuse and deportation to overcrowded and unhealthy living situations and limited access to healthcare. Table 1 illustrates the factors contributing to a sense of insecurity, highlighting several of the indicators noted in the previous section. While the table reports certain indicators related to gender, information about female participants' experiences with sexual and domestic abuse and exploitation is not available due to methodological constraints.

As the table indicates, many of the participants, both women and men, experience economic hardship in Jordan. While this table is not intended to be representative of the Iraqi forced migrant population in general, ${ }^{74}$ it relates to the factors of a vulnerability context mentioned above and it frames a context in which they interpreted their experiences trying to access official sources of information.

Eighty percent of participants described using or attempting to get official information, often in the form of details about their status, the structure of the resettlement process, or conditions in resettlement states. During interviews, research participants shared their experiences trying to get in touch with UN or other agency offices. The more participants portrayed their interactions with official sources of information, the clearer it became that these experiences were influenced by and also heightened their sense of insecurity.

(C) Adam Saltsman, 2011. This open-access work is licensed under a Creative Commons Attribution-NonCommercial 4.0 International License, which permits use, reproduction and distribution in any medium for non-commercial purposes, provided the original author(s) are credited and the original publication in Refuge: Canada's Journal on Refugees is cited. 
Table 1: Indicators of Insecurity

\begin{tabular}{|c|c|c|c|}
\hline Indicators & $\%$ Participants & Male & Female \\
\hline \multicolumn{4}{|c|}{ Financial resource/employment } \\
\hline $\begin{array}{l}\text { Unhealthy living } \\
\text { conditions }\end{array}$ & 32 & 4 & 4 \\
\hline Debt & 40 & 6 & 4 \\
\hline Overcrowded housing & 32 & 2 & 6 \\
\hline $\begin{array}{l}\text { Below the Jordanian } \\
\text { poverty line }\end{array}$ & 36 & 3 & 6 \\
\hline Labour exploitation & 8 & 1 & 1 \\
\hline \multicolumn{4}{|l|}{ Health } \\
\hline $\begin{array}{l}\text { Physical health } \\
\text { problems }\end{array}$ & 24 & 2 & 4 \\
\hline \multicolumn{4}{|l|}{ Gender } \\
\hline $\begin{array}{l}\text { Female-headed } \\
\text { household }\end{array}$ & 20 & & 5 \\
\hline $\begin{array}{l}\text { Single female below } \\
\text { poverty line }\end{array}$ & 16 & & 4 \\
\hline Gender (other) ${ }^{b}$ & 8 & & 2 \\
\hline \multicolumn{4}{|c|}{ Relations with host community } \\
\hline $\begin{array}{l}\text { Problems with } \\
\text { neighbours }\end{array}$ & 20 & 2 & 3 \\
\hline \multicolumn{4}{|l|}{ Immigration/legal status } \\
\hline Deportation & 0 & 0 & 0 \\
\hline Police harassment & 12 & 3 & \\
\hline
\end{tabular}

a. According to USAID, the poverty line in Jordan is USD \$439 per capita annual income.

b. This category refers to a range of gender-related issues which respondents faced and that indicate their vulnerability, such as generalized disenfranchisement in decision-making as a result of one's gender.

\section{As 27-year-old Jaber noted:}

When I go to meet with the social counselor [at UNHCR], she says that she doesn't know where my file is and that I need to call by phone if I want to find out something related to my status. But when I call, they keep me on hold forever, like an hour, transferring me from one person to the next, until I run out of phone credit. And then that's that.

Forty-nine-year-old Nadia, who has been living in Jordan for two years, also felt that the environment at UNHCR is less conducive to information sharing and more about information extraction:

I would like that everything can be made more clear. My last interview was like an argument. They said they didn't know anything and we said that we needed to know the information. It is like an investigation - they just take notes and say that they need to know this and that, but what is the use of this information?

Such excerpts from across the sample of participants construct a narrative of inaccessible and unwelcoming institutions; even if such institutions truly do not "know anything," the context is one of such extreme insecurity that it is impossible for some participants to believe no answer exists to questions regarding their future. Other comments reflect the notion that while these institutions do give out some information, it is not tailored to meet migrants' needs. As 30-year-old Saphir put it:

The only information we are getting from the UN is from the brochures and from the advertising and other than that we don't have any kind of information. If we need to ask, we can't ask, we are only getting ... getting ... we are only getting information that they want us to have, not what we are asking about.

The brochures mentioned here are informational pamphlets about services available to Iraqis in Jordan and about repatriation. Several of the research participants had seen the larger posters or pamphlets distributed by UNHCR regarding financial support for those who wish to return to Iraq. However, as 33-year-old Sharin explains it, this information is only partial:

I read about assistance for repatriation. I read that the UN will give $\$ 100$ for people volunteering to go back. I also heard this while waiting at Caritas. I heard that it is $\$ 100$ per person and the family will get no more than $\$ 500.00$. I've not heard anything about what happens to people who go back.

For some, like Nadia who attended information sessions, receiving institutional details was only secondary to the fact that "I just want to know where my file is-this uncertainty means I don't know what my life will be like two months from now."

For 28-year-old Ahmed, it is his tenuous ability to remain in Jordan that causes him anxiety because of what he fears in Iraq:

I heard that for my process [with the UN] I need to present documents, which I did. Also if I received some death threats, I need to show the paper which the threat was written on or I need to show photos that prove my situation. I presented my case three years ago and haven't gotten anywhere. In the meantime a year and a half ago my uncle was murdered in Iraq. Two months ago, my other uncle was murdered. I got the death certificate for this to prove it. But now they are sending death threats for my father. 
I gave all of this information to UNHCR but I still haven't heard anything from them.

Figure 1: Influential links affecting experiences

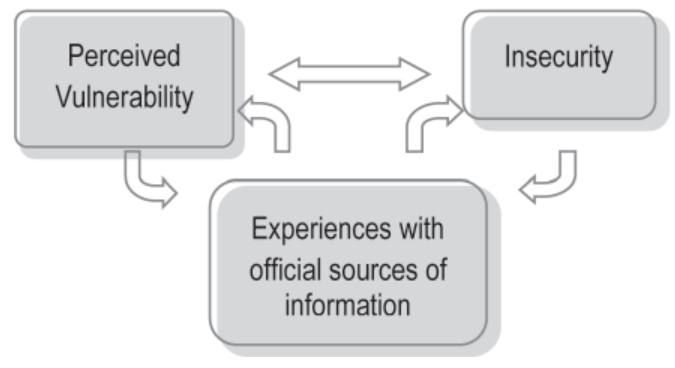

Ahmed had been receiving cash assistance from one humanitarian organization in Jordan before their program ended and as a result this form of support evaporated. Unable to work, in debt, and with no income from remittances, Ahmed lost his apartment and moved into an empty office building where he lived without a bathroom or kitchen.

In this state of insecurity, Ahmed expressed frustration at the international community. "I didn't receive any information about anything," he said. "No resettlement and no help. I get monthly assistance from the UN but that's it and it's not enough ... I am hanging by a thread here." Frustrated with this perceived silence and delay from the UN, Ahmed has frequently called and visited their offices to get some further details about his case. "A year ago I contacted the $\mathrm{UN}$ and asked about my file and they said that it was under study," he said. "A month ago they said the same thing ... I want to know what the process is. What is the procedure? I just want a reply, yes or no. I feel devastated."

It is the uncertainty in and of itself that causes Ahmed such stress as he reflects on possible next steps:

I have definitely thought about going illegally. I know a lot of people who have been contacted by an individual saying that if given money they can give you a visa. If he comes and talks to me, I'll go for it. There is no other way and I can't go back to Iraq.

This could include any manner of risky travel where, as mentioned above, migrants are often subject to exploitation, theft, and abuse at the hands of smugglers, traffickers, and government officials they meet or upon which they rely along the way.

These accounts reflect the ways in which being in a "vulnerability context" is directly connected to a sense of insecurity, which in turn compounds frustration with these agencies' perceived lack of transparency. Figure 1 illustrates this interconnection.

While these links are not causal, they reflect the ways in which participants' vulnerability and sense of insecurity relate to one another and to their experiences attempting to acquire official information. In Ahmed's case, his initial state of vulnerability leads to a sense of insecurity, both of which colour his experience at the UNHCR office. In turn, his experiences at the UN-and his frustration with these experiences-heighten his sense of insecurity, which influences his decision to migrate irregularly, an option that would drastically increase his vulnerability.

\section{Mistrust and Negative Perceptions of Official Sources of Information}

Participants demonstrate that their sense of insecurity also leads to a mistrust of the institutions regulating resettlement and repatriation. Some consider institutional information highly valid, but their situation has pushed them to question the role of the agencies providing protection and assistance. A number of participants felt a loss of trust precisely because of their lack of access to information. Feeling that institutions managing the resettlement process are withholding information, giving it only partially, or forsaking their Iraqi beneficiaries led many participants to label these agencies as untrustworthy:

We need to have a mechanism to give beneficiaries information about their cases so that they will know what the timeline is for everything because the UN tells you sometimes that in nine months you will be in the United States, so ... but you stay for a year and a half and nothing happens so you get worried about that. I know that they have a lot of pressure and a lot of refugees in Jordan and this makes a lot of work, but this is not ... they need to explain their mechanism so people would relax a little bit and because ... uh ... it is not trustworthy anymore, we can't depend on the information anymore.

In this excerpt, Saphir links the condition of uncertainty and waiting - a condition shown above to be interconnected with vulnerability and insecurity - to a growing mistrust of the information that comes out of agencies such as UNHCR. During a focus group with four middle-aged Iraqi research participants, the following discussion builds on Saphir's point:

ADAM: What have been your experiences meeting officials to talk about your options for the future?

Do'A: A lot of social workers and case managers came and asked us the same questions each time they met us. They want details about us, but then nothing happens and we don't get services. I 
feel tired out from all of this and if I could get something from this whole process if there is some benefit, then let me see it, otherwise you are wasting my time.

ZaInA: It's not just about losing trust. It feels like there's neglect of us. In general, Iraqis don't have trust in the people we meet during our appointments and we don't trust the information that is given to us.

Figure 2: Mistrust, information, and vulnerability

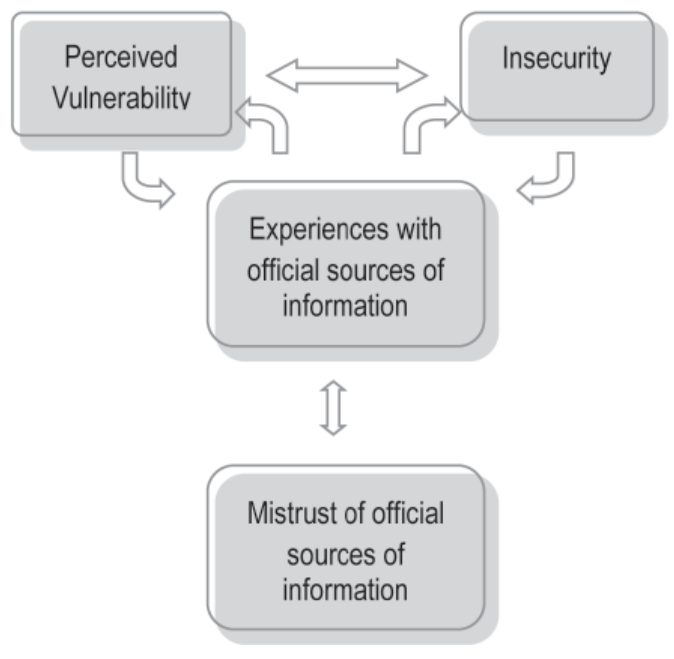

At another point during the same focus group, the conversation returned to trust:

Aвu Mohamed: When we go to the UN, nobody tells us the truth. Nobody answers our calls, or at least this is how it was a few months ago. Maybe it's improved since then.

DOA'A: Right.

OM NooR: Right. They just give us information to calm us down, they just give us useless information.

DoA'A: We want information about immigration.

Ави МонамеD: Yesterday I called UNHCR to ask about taking my son to the doctor and nobody answered. The operator was busy. I wanted to get the phone number for Caritas, but the person at UNHCR didn't give me the information.

Here, participants associated a feeling of neglect with a sense of mistrust-an outcome of a collapse in the belief that these organizations would fulfill their purported commitment to providing protection and/or assistance to migrants. Following his accusations of neglect and opaqueness, Abu Mohamed's story in which UNHCR's inaccessibility got in the way of his taking his son to the doctor reflects the relationship between vulnerability and mistrust. Mistrust also stems from the perception that official institutions solicit information but do not give it or deliver on the promises that come implicitly with such inquiry. Finally, Om Noor appears angered at the notion that agencies use information as a tool to control and pacify Iraqis. Adding to Figure 1, Figure 2 illustrates the role of mistrust in this dynamic.

As this diagram shows, the mistrust participants expressed toward official sources of information is a result of their experiences with the institutions regulating resettlement and return. However, the relationship is cyclical in that growing mistrust then colours subsequent experiences at state and supra-state agencies.

\section{Ongoing Reliance on Local Knowledge Networks}

Perhaps one of the largest factors shaping participants' experiences with official sources of information is their use of local knowledge networks for co-constructing experiential accounts of the migratory process. The term "local" here is adopted from Smith's notion of "local knowledge," mentioned above. These networks exert an influence and are influenced by migrant perceptions of official institutions. But, just like their perceptions of state and supra-state agencies, migrants' use and perception of local knowledge networks are also subject to the pressures of an unstable situation. As Geraldine Chatelard asserts, Iraqi migrations are positioned along networks established and maintained through multiple waves of displacement. ${ }^{75}$ Iraqis migrating outwardly have maintained connections in Iraq, have diasporic relations with Iraqis in multiple parts of the world, engage in cross-border political activities, and-when conditions allow-have travelled back and forth between homes in Iraq and abroad. These transnational relations form communication networks that serve as migratory capital for the exchange of local knowledge.

Through conversations with resettled refugees and Iraqis who have lived abroad for decades, Iraqis displaced in Jordan have a chance to hear first-hand accounts of the life one faces abroad. Research participants described a reliance on the stories told by other Iraqis going through the resettlement process in Jordan or Iraqis who have been to resettlement countries:

ADAM: Where have you heard information about resettlement and repatriation?

SAMIR HAMDI: I heard from people who went already or those who have relatives there.

Sun: From people who have been there and described the situation.

MAI: My cousin has been living in America for four years. I got information from there.

KALB HAZN: I got information from street talk. From a group of Iraqis. This is the only topic that we ever discuss.

MoнAmed: I called two people who have resettled in different 
states. One said that it is ok and the other said it is terrible; he is devastated. Generally I get information from the streets. SAmir Hamdi: Like when we visit homes, we talk about this. MAI: We don't go and ask IOM or UNHCR for information. You get information from there only after you are accepted for resettlement. They have a class, but it is very vague and simple. And the information was very discouraging.

Participants gather local experiences in multiple ways. Mohamed locates his base of knowledge "on the streets." This seems to be an analogy for informal sources on a local level, whether they are close in proximity or far away in other countries. Mai specifies her reliance on relatives abroad for details about their experiences. In terms of questions about repatriation, Youssef put it:

My family in Iraq tells me that the best thing I did was to leave and keep my family safe. In terms of services, those who are already there do not get any services at all so how can there be services for you if you come back. It is better to stay away, even if it means being apart from your family. Things are worse than before with the US leaving. Things are upside down. Now that the US pulled out, there is no way to return.

In this case, his use of familial contacts in Iraq proves sufficient to discourage Youssef from returning at this time.

To some extent, these networks thrive on the humanitarian spaces provided by non-governmental organizations and international and state agencies:

ADAM: So you hear from people who come from Iraq to Jordan and then how do you know these people?

SAPHIR: For two years I've worked with humanitarian organizations in Jordan. Of course from people who come to CARE and other organizations. Because anyone coming from Iraq was in a hurry and doesn't have the money in order to live here in Jordan so they come here or to the United Nations. Directly, they go to UNHCR. Because of course these people will go to UNHCR and UNHCR will give them brochures and information about organizations that give services to Iraqi refugees, when they come to CARE or other organizations, I meet them and I hear the news from them. And Amman is a small city so people know each other. People go to organizations and meet each other. One tells the rest of the people information that he experienced in Iraq or if someone went to the USA and returned to Jordan he will tell people.

As Saphir explains, the physical spaces of international NGOs become impromptu locales for the exchange of experiential knowledge. As Iraqi forced migrants sit waiting in reception rooms, they have the opportunity to co-construct knowledge about options for the future. These exchanges are more than just knowledge transactions. Forty-two-year-old
Noor finds herself utterly alone in Jordan, having lost her husband and five children to the conflict in Iraq:

When you find that you don't have a country and you find somebody from your country, you like to gather with them to hear the language, to feel like you have a family and also to talk about immigration, IOM. We meet in the NGOs.

Thus displaced Iraqis have the opportunity to widen their social network, their migratory capital, and their community support structures via the space of humanitarian organizations. Research participants, like 33-year-old Moi, assert that these exchanges, which are established in the space of NGOs or refugee camps, turn into networks spanning geographical boundaries when contacts resettle or continue some other way onto the next step of their migration. Moi notes that he has friends all over North America and in Europe:
ADAM: Where are some of the contacts you rely on for information?
MoI: America. Friends in the US. West Virginia, Pennsylvania. Also in Canada, my friend is there, and in England I have friends. They are all friends, not relatives. Only my brother in the United States, in Pennsylvania. I call them and they call me. They are from here. I know them from here. In Baqa'a, in Jordan. And from Jordan they go, they get resettled to the USA, to Canada, and to Europe and we stay in touch by phone.

The informal interactions taking place between Iraqis in humanitarian spaces are in a context in which official information is also available. Several international NGOs have recently set up "information centres" throughout Jordan primarily to further the proliferation of information about repatriation, though some focus on resettlement. The physical spaces in which this official information is available also remain ideal locales for the co-construction of local knowledge.

In addition, there are certain agency actors who may occasionally deviate from their duty to give only scripted information to Iraqi forced migrants. For 38-year-old Farah and her husband, the knowledge leaked from UNHCR staff was a deciding factor:

I asked a UN worker to explain what I might find in America, whether the kids get monthly assistance. The answer was no, that neither we nor our kids get assistance. They cover us for three months and then we are on our own. After we heard that we felt down and started really thinking about not going... . Later we asked for our file to be pulled and when they asked us why we did that, we told them it was for financial reasons. 
According to research participants, Iraqi forced migrants maintain local knowledge networks predominately through phone or in-person discussion. However, 12 percent of participants (3 out of 25) reported relying on online networks to email contacts living outside of Jordan or participate in a web discussion forum for Iraqis:

This forum has information about people's experience ... They tell their stories about what's happened with them, what happened at the airport, what did the agency give them when they got to the airport, how much did they give them, about the food stamps and the medical thing ... People from all countries, Lebanon, Syria, US, and Australia - all these kind of countries, they tell the stories about ... how everything went with them and [they] explain it to people in the forum.

\section{Insecurity, Mistrust, and Local Knowledge}

Participants' sense of insecurity and their mistrust of state and supra-state agencies influenced use of and contributions to the circulation of experiential knowledge. Research participants became acutely aware that refugee processing involved textualizing lived experiences to render them measurable according to administrative and legal standards in part by relying on accounts heard from other displaced Iraqis.

For example, as 45-year-old Mara'a put it, "I have heard very strong rumors that if you lie and dramatize your story, then you will get resettled, but if you tell the truth then it is likely that they will reject you." Echoing this, 47-year-old Youssef said:

Each case is different. It depends on what happened for that person in Iraq. But there are many people who present fake photos and CDs with videos or photos on them that illustrate persecution or death threats. There are forged certificates of certain experiences. It's funny because the people who bring these forged documents and photos are the ones who get accepted for resettlement and they leave for America while a family with a son that has real documents and proof of his persecution will be stuck and will not get accepted.

This reflects suspicion of both the institutions managing migration and of other Iraqis who seem to have committed fraud and succeeded. These lines should also be read as signals of uncertainty; research participants searched for meaning in the fact that they may have been rejected from resettlement or forgotten about by humanitarian agencies despite having had-or continuing to have-life experiences with insecurity that warrant a need for international protection. As much as these excerpts are accusations of a
Figure 3: Interaction between local knowledge \& official information

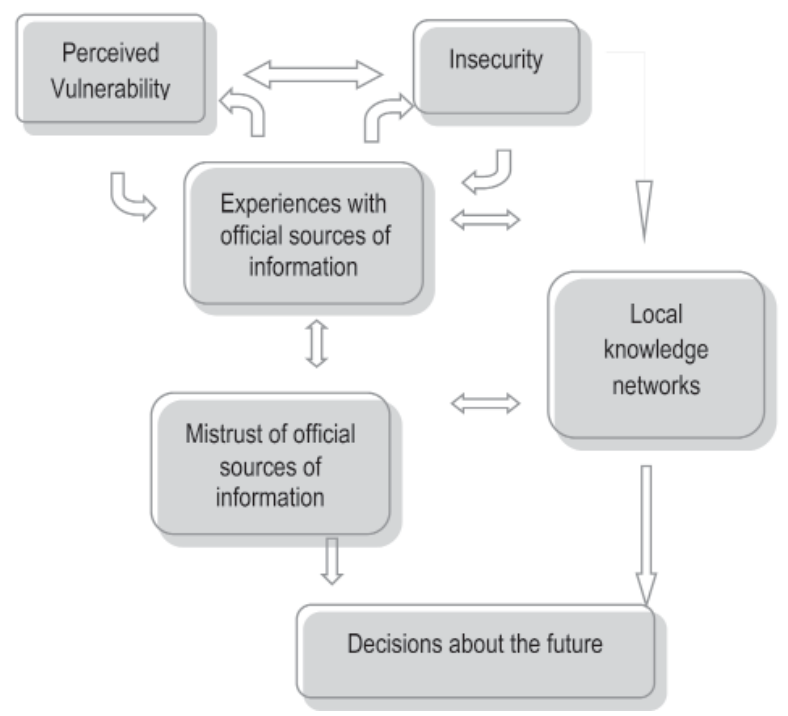

fraudulent resettlement process, they are also demonstrations of how participants relied on others' accounts as they formulated perceptions of their testimonies' utility during the official and systematic processing of data on refugees.

Many of the stories shared by participants constitute hearsay about the resettlement process. Both personal accounts and stories passed along from person to person influenced participants. Participants also tended to rely on hearsay when it came to stories about projected insecurity. According to 39-year-old Sun,

I got through the process of resettlement. I did the procedures-I am waiting for the final result but still hesitating. I don't know if I should stay or go. I am terrified of going ... But I am scared that if I say no, the UN will take away my papers and I will have to go back to Iraq. My sister is in Sweden and they told me that I couldn't go be with her. They told me to just take my opportunity for resettlement or leave it.

In this case, Sun considers information from UNHCR, rumours and accounts from other Iraqis, and her own sense of insecurity as she tries to make up her mind. For some research participants, their growing mistrust of the institutions regulating migration is what leads them to favour experiential knowledge. As Saphir stated,

I know that on a personal level I don't trust the information given from the UN and the IOM but the thing is that as a person I like more to get information from people with experience that ... they got resettled and they went to the countries. Why? Because I imagine the path of my life and what is going to happen to me and

(C) Adam Saltsman, 2011. This open-access work is licensed under a Creative Commons Attribution-NonCommercial 4.0 International License, which permits use, reproduction and distribution in any medium for non-commercial purposes, provided the original author(s) are credited and the original publication in Refuge: Canada's Journal on Refugees is cited. 
how everything will go. But that doesn't mean that the information that we have from the UN or IOM websites and all kind of resources is not important because it is. It is the formal kind of information and it is very important for the refugees. We have some kind of code in Arabic: "you can ask someone with experience and not ask the doctor" like we trust someone with experience more than we trust the doctor.

Despite recognizing that at times accounts from other Iraqis may not be accurate, Saphir reflects, "I take them more seriously because they may not be true $100 \%$, but because they are real experiences."

The cyclical relationship between living in a state of insecurity, experiences with official sources of information, mistrust of these sources, and negotiating the local knowledge circulating among Iraqi forced migrants led to real consequences for several research participants. Sixteen percent of participants reported that they had declined an offer of resettlement in the recent past. In most cases, these decisions were made strategically to preserve or enhance physical or psychological security. As Doa'a's words below indicate, these decisions were also often made based on experiential knowledge and hearsay, sources of information that are more trusted than those official locales:

I got accepted to the United States and I refused to go based on the information I got from a relative there. She told me that you only get 3 months of assistance and don't get any help after that and you can't survive.

To add to the model shown in Figures 1 and 2, Figure 3 illustrates the link between vulnerability, insecurity, mistrust, and participants' experiences with official sources of information.

As this model shows, decisions about the future for research participants are based on far more than the information they get from official sources of information. These decisions are also based on more than local knowledge networks. Rather they appear to be products of an interface between the two as processes affected by trust, notions of security, and an overall context of vulnerability. Reliance on experiential knowledge is not necessarily causally linked to the unavailability of official information as West and Wambugu suggest. ${ }^{74}$ Rather it takes place parallel to what happens with official information and each tends to influence the other.

\section{Conclusion}

Despite an overarching organizational commitment to providing information about options for the future to displaced persons, a restrictive framework nevertheless emerges when the stability of administrative processes prevails over individual forced migrant requests. Actual practices regarding information suggest an institutional desire to remain in control of the migratory process and it appears to assume that Iraqi forced migrants have no recourse to such information through alternative means. The defensive posturing on the part of these agencies may be an important safeguard for agency staff, but in terms of information, research participants have described how this reticence constructs an adversary relationship.

Despite this tendency, there is a proliferation of local knowledge exchanged transnationally. The study locates its lens at the nexus of lived experience and official information, pointing to the ways in which Iraqi forced migrants may see their lived experience and that of other migrants turned into the objectified information of institutions that regulate migration. At the same time, participants demonstrate that they call upon a variety of resources that are available via transnational communication networks. These networks provide the local knowledge of thousands of Iraqis whose lived experiences constitute migratory capital for those forced migrants attempting to make a decision about where to go. While participants will likely always depend on their networks for experiential knowledge, current and projected insecurity clearly has an impact on how they see this knowledge and how they put it into dialogue with their perceptions of state and supra-state agencies. As humanitarian agencies restrict the flow of official information, they are unwittingly engaging both forced migrants' senses of insecurity and their reliance on transnational networks. The attention to trust and security in this paper should guide subsequent work to look at the experiences of displaced Iraqi women regarding access to official information and local knowledge networks. Women forced migrants as a category experience a higher level of violence and vulnerability, ${ }^{75}$ a point Nasrallah and Washington underscore in their report on Iraqi women in Syria who are sold into or who engage in sex work. ${ }^{76}$

This study has pointed to an understudied component of displacement, mobility, and the management of migrating groups. A transnational focus on the migratory capital of research participants brings greater clarity to how Iraqi forced migrants build and maintain social networks with one another. ${ }^{77}$ As Van Hear states, the challenge for agencies like UNHCR is to reconcile their mandate and ways of working "with recognition that transnational connections and practices provide important means for sustaining people caught up in conflict, displacement, and its aftermath."78 Thus, the study aims to highlight the value of supporting initiatives contributing to migratory capital, a set of resources on which forced migrants often depend just as 
much as they rely on the protection of international agencies. Rather than relying on a model of universal protocol, UNHCR and other agencies should both increase their transparency vis-à-vis the refugee and engage the sorts of local and transnational initiatives that spring up as survival mechanisms in contexts of displacement. The failure to do either will only aggravate the unintended consequences of humanitarian interventions instead of consolidating greater regulatory power for the international refugee regime over the forced migrant population.

\section{Notes}

1. UN High Commissioner for Refugees, 10-Point Plan Expert Round Table No. 2: "Different People, Different Needs" (Tunis, Tunisia, 6-8 July 2009). Summary Report, 29 September 2009, accessed October 14, 2010, http://www unhcr.org/refworld/docid/4ae15db72.html; Inter-Agency Standing Committee, Handbook for the Protection of Internally Displaced Persons, December 2007, accessed April 21, 2010, http://www.unhcr.org/refworld/docid/4790cbc02 .html; UNHCR, Operational Protection in Camps and Settlements. A Reference Guide of Good Practices in the Protection of Refugees and Other Persons of Concern, June 2006, accessed October 14, 2010, http://www.unhcr.org /refworld/docid/44b381994.html.

2. Universal Declaration of Human Rights, Article 19, General Assembly Resolution 217 A (III), 10 December 1948. See also Article 19 of the International Covenant on Civil and Political Rights, General Assembly Resolution 2200A (XXI), 21 U.N. GAOR Supp. (No. 16).

3. UNHCR, Operational Protection.

4. UNHCR, Operational Protection, 58.

5. Ibid.

6. Amy R. West and Lydia W. Wambugu, Left to Their Own Devices: The Impact of Informal Information and Communication Networks on Security in the Tanzanian Refugee Camps (London: Article 19, 2003).

7. E. Valentine Daniel and John Chr. Knudsen, "Introduction," in Mistrusting Refugees, ed. Daniel E. Valentine and John Chr. Knudsen (Berkeley: University of California Press, 1995); West and Wambugu, Left to Their Own Devices.

8. Bill Frelick, "Paradigm Shifts in the International Responses to Refugees," in Fear of Persecution: Global Human Rights, International Law, and Human Well-Being, ed. James Daniel White and Anthony J. Marsella (Lanham, MD: Lexington Books, 2007), 33-57; B. S. Chimni, "Aid, Relief, and Containment: The First Asylum Country and Beyond," International Migration 5 (2003): 75-94; B. S. Chimni, "From Resettlement to Involuntary Repatriation: Towards a Critical History of Durable Solutions" (Working Paper No. 2, New Issues in Refugee Research, UNHCR, Geneva, 1999); Jennifer Hyndman, Managing Displacement: Refugees and the Politics of Humanitarianism, Borderlines,
Vol. 16 (Minneapolis, MN: University of Minnesota Press, 2000); Thomas A. Aleinikoff, "State-Centered Refugee Law: From Resettlement to Containment," in Michigan Journal of International Law, 14 (1992): 120-38.

9. UNHCR, Handbook of Voluntary Repatriation: International Protection (Geneva, 1996), accessed May 20, 2010, http://www.unhcr.org/ refworld/docid/3ae6b3510.html.

10. UNHCR, Resettlement Handbook (country chapters last updated September 2009), 1 November 2004, accessed April 21, 2010, http://www.unhcr.org/ refworld/docid/3ae6b35e0 .html.

11. Khalid Koser, "Information and Repatriation: The Case of Mozambican Refugees in Malawi," Journal of Refugee Studies 1 (1997): 1-18.

12. West and Wambugu, Left to Their Own Devices, 24.

13. Geraldine Chatelard, "What Visibility Conceals: Reembedding Refugee Migration from Iraq," in Displacement and Dispossession: Forced Migration in Africa and the Middle East, ed. Dawn Chatty (London: British Academy, 2009); Robert C. Smith, Mexican New York: Transnational Lives of New Immigrants (Berkeley, CA: University of California Press, 2006); Robert C. Smith, "How Durable and New Is Transnational Life? Historical Retrieval through Local Comparison," Diaspora 2 (2002): 203-34; Alessandro Monsutti, War and Migration: Social Networks and Economic Strategies of the Hazaras of Afghanistan (New York: Routledge, 2005); Roger Waldinger and David Fitzgerald, "Transnationalism in Question," American Journal of Sociology 5 (2004): 1177-95; Steven Vertovec, "Migrant Transnationalism and Modes of Transformation," International Migration Review 3 (2004): 970-1001; Rainer Baubock, "Towards a Political Economy of Migrant Transnationalism," International Migration Review 3 (2003): 700-23; Alejandro Portes, "Conclusion: Theoretical Convergencies and Empirical Evidence in the Study of Immigrant Transnationalism," International Migration Review 3 (2003): 874-92; Peggy Levitt, Josh DeWind, and Steven Vertovec, "International Perspectives on Transnational Migration: An Introduction," International Migration Review 3 (2003): 565-75; Peggy Levitt, Transnational Villagers (Berkeley, CA: University of California Press, 2001); Jorge Duany, "Nation on the Move: The Construction of Cultural Identities in Puerto Rico and the Diaspora," American Ethnologist 1 (2000): 5-30; Roger Rouse, "Questions of Identify: Personhood and Collectivity in Transnational Migration to the United States," Critical Anthropology 4 (1995): 351-80; Nina Glick Schiller, Linda Basch, and Cristina Szanton-Blanc, "From Immigrant to Transmigrant: Theorizing Transnational Migration," Anthropological Quarterly 1 (1995): 48-63; Linda Basch, Nina Glick Schiller, and Cristina Szanton Blanc, Nations Unbound: Transnational Projects, Postcolonial Predicaments, and Deterritorialized Nation-States (Amsterdam: BV Publishers, 1994).

14. Basch, Glick Schiller, and Szanton-Blanc, Nations, 7. 
15. Peggy Levitt and Nina Glick Schiller, "Conceptualizing Simultaneity: A Transnational Social Field Perspective on Society," in Rethinking Migration: New Theoretical and Empirical Perspectives, ed. Alejandro Portes and Josh Dewind (New York: Berghan Books, 2007), 181-218; Monsutti, War and Migration.

16. Levitt and Glick Schiller, "Conceptualizing Simultaneity"; Stephen Castles, "Migration and Community Formation under Conditions of Globalization," International Migration Review 4 (2002): 1143-68.

17. Peggy Levitt, "Routes and Roots: Understanding the Lives of the Second Generation Transnationally," Journal of Ethnic and Migration Studies 7 (2009): 1225-42; Steven Vertovec, "Migrant Transnationalism and Modes of Transformation," in Rethinking Migration: New Theoretical and Empirical Perspectives, ed. Alejandro Portes and Josh Dewind (New York: Berghan Books, 2007), 149-80; Deborah Bryceson and Ulla Vuorella, The Transnational Family: New European Frontiers and Global Networks (Oxford: Berg, 2002); Levitt, Transnational Villagers; Alejandro Portes, Luis E. Guarnizo, and Patricia Landolt, "The Study of Transnationalism: Pitfalls and Promise of an Emergent Research Field," Ethnic and Racial Studies 2 (1999): 217-37; Levitt and Glick Schiller, "Conceptualizing Simultaneity."

18. UNHCR, Global Appeal 2010-2011 (Geneva, 2009), accessed October 26, 2010, http://www.unhcr.org/ga10 /index.html\#/home.

19. Smith, Mexican New York; Waldinger and Fitzgerald, "Transnationalism in Question"; Levitt, Transnational Villagers; Luis E. Guarnizo, "On the Political Participation of Transnational Migrants: Old Practices and New Trends," in E Pluribus Unum? Contemporary and Historical Perspectives on Immigrant Political Incorporation, ed. Gary Gerstle and John H. Mollenkopf (New York: Russell Sage Foundation, 2001), 213-63; Nina Glick-Schiller, "Transmigrants and Nation-States: Something Old and Something New in the U.S. Immigrant Experience," in The Handbook of International Migration: The American Experience, ed. Charles Hirschman, Philip Kasinitz, and Josh Dewind (New York: Russell Sage Foundation, 1999) 94-119; Luis E. Guarnizo and Michael P. Smith, "The Locations of Transnationalism," in Transnationalism from Below, ed. Luis E. Guarnizo and Michael P. Smith (New Brunswick, NJ: Transaction Publishers, 1999), 3-34.

20. Nicholas Van Hear, New Diasporas: The Mass Exodus, Dispersal and Regrouping of Migrant Communities (Seattle, WA: University of Washington Press, 1998); Anthony H. Richmond, Global Apartheid: Refugees, Racism and the New World Order (Oxford: Oxford University Press, 1994).

21. Hannah Arendt, The Origins of Totalitarianism (New York: Harcourt, 1968), 294.

22. Swanie Potot, "Le réseau migrant: une organisation entre solidarité communautaire et 'zone de libre échange," Migrations Société 105-6 (2006): 49-74; Monsutti, War and Migration; Van Hear, New Diasporas.
23. Nicholas Van Hear, "Refugees in Diaspora: From Durable Solutions to Transnational Relations," Refuge 1 (2006): 11.

24. Ibid.

25. Van Hear, New Diasporas, 50.

26. Pierre Centlivres, "Le Moyen-Orient et nous: point de vue de l'anthropologue," Synergies, edition speciale (1995): 38.

27. Monsutti, War and Migration.

28. Dorothy Smith, Texts, Facts, and Femininity: Exploring the Relations of Ruling (London: Routledge, 1990).

29. Ibid.

30. Ibid., 15 .

31. Ibid., 31 .

32. As migrants experience assessment and categorization, they are also experiencing the discretion of what Lipsky refers to as "street-level bureaucrats," those actors who perform the implementation of policy through their interactions with and management of the public; Michael Lipsky, StreetLevel Bureaucracy: Dilemmas of the Individual in Public Services (New York: Russell Sage Foundation, 1980).

33. Geraldine Chatelard, Protection, Mobility and Livelihood Challenges of Displaced Iraqis in Urban Settings in Jordan (Geneva: International Catholic Migration Commission, 2009); Chatelard, "What Visibility Conceals"; Geraldine Chatelard, "Jordan as a Transit Country: Semi-protectionist Immigration Policies and Their Effects on Iraqi Forced Migrants" (New Issues in Refugee Research, Working Paper No. 61, UNHCR, Geneva, 2002).

34. Chatelard, Protection.

35. Ibid.

36. Joseph Sassoon, The Iraqi Refugees: The New Crisis in the Middle East (London: I.B. Tauris, 2009); Chatelard, "Jordan as a Transit Country."

37. Sassoon, The Iraqi Refugees; Fathi Arouri, "Irregular Migration in Jordan 1995-2007," CARIM Analytic and synthetic notes 2008/71, European University Institute, Robert Schuman Center for Advanced Studies, 2008, accessed October 26, 2010, http://hdl.handle.net/1814/10116.

38. International Crisis Group, "Failed Responsibility: Iraqi Refugees in Syria, Jordan, and Lebanon," Middle East Report No. 77, 2008, accessed October 26, 2010, http:// www.crisisgroup.org/en/regions/middle-east-north-africa/ iraq-syria-lebanon/iraq/077-failed-responsibility-iraqi -refugees-in-syria-jordan-and-lebanon.aspx.

39. UNHCR, Statistical Report on registered Iraqis in Syria, Jordan, Lebanon, Turkey and Egypt, 2008, accessed October 26, 2010, http://www.unhcr.org/491959312.pdf. This number is believed to be relatively stable as the number of newly arrived asylum seekers counterbalances the number of refugees leaving for resettlement.

40. UNHCR, Statistical Report; International Crisis Group, Failed Responsibility.

41. Fafo, UN Population Fund, Government of Jordan, Iraqis in Jordan 2007: Their Number and Characteristics, 2007, accessed October 26,2010, http://www.fafo.no/ais/middeast /jordan/IJ.pdf. The statistic for the number of Iraqis in this 
report comes from Jordanian immigration statistics, phone subscribers, and a household survey conducted in May 2007. It is important to note that Fafo published this number as an adjustment to their initial findings of 161,000 (see p. 7).

42. Chatelard, Protection.

43. "Iraqis, Afghans, and Somalis top list of asylum seekers in industrialized world," UNHCR Press Release, October 21, 2009, accessed April 27, 2010, http://www.unhcr .org/4adf24079.html.

44. Human Rights Watch, Stuck in a Revolving Door: Iraqis and Other Asylum Seekers and Migrants at the Greece/Turkey Entrance to the European Union (Washington, D.C.: Human Rights Watch, 2008), 27. See also "REFUGEES: UNHCR concerned over Iraqi deportations," IRIN, September 29, 2010, accessed October 26, 2010, http://www .alertnet.org/thenews/newsdesk/IRIN/d8c7a728fce0c c6c240297a9be421c1a.htm.

45. Karen Jacobsen, "Editorial Introduction: Refugees and Asylum Seekers in Urban Areas: A Livelihoods Perspective," Journal of Refugee Studies 3 (2006): 273-86; Machtelt DeVriese, Refugee Livelihoods: A Review of the Evidence (UNHCR EPAU/2006/04); Benedikt Korf , "War, Livelihoods and Vulnerability in Sri Lanka," Development and Change 2 (2004): 275-95.

46. Jeff Crisp, Jane Janz, and José Riera, Surviving in the City: A Review of UNHCR's Operation for Iraqi Refugees in Urban Areas of Jordan, Lebanon, and Syria (UNHCR PDES/2009/03); Jacobsen, "Editorial Introduction."

47. In UNHCR's evaluation, these constraints were not listed as primary indicators of vulnerability, but were listed as indicators for the improvement of protection space in Jordan, Lebanon, and Syria for Iraqi forced migrants. They can thus be seen as current gaps in protection to be addressed by UNHCR; thus they are also indicators of vulnerability. See Crisp, Janz, and Riera, "Surviving in the City."

48. Sassoon, The Iraqi Refugees; Women's Commission for Women and Children, Iraqi Refugees in Jordan: Desperate and Alone, 2007, accessed October 26, 2010, http:// womensrefugeecommission.org/docs/iq_brief.pdf).

49. Human Rights Watch, The Silent Treatment: Fleeing Iraq, Surviving in Jordan (Washington, D.C.: Human Rights Watch, 2006), accessed October 26, 2010, http://www.hrw .org/en/node/11107/section/1; International Rescue Committee, Five Years Later: A Hidden Crisis, 2008, accessed October 26, 2010, http://www.theirc.org/sites/default/files /migrated/resources/2008/iraq_report.pdf; Amnesty International, Rhetoric and reality: The Iraqi refugee crisis, 2008, accessed October 26, 2010, http://www.amnesty.org/en /library/info /MDE14/011/2008/en; Nina Gora, "Provision of Legal Services in Jordan" (Legal Aid, unpublished report, 2009, on file with the author).

50. Amnesty International, Rhetoric and reality. Iraqis who are not investing in Jordanian businesses must prove that they have the equivalent of $\$ 150,000$ in a Jordanian bank account.

51. One respondent for this study who was an engineer in Iraq reported being caught by Jordanian authorities for consulting with an engineering firm in Jordan. Jordanian authorities deported him to Iraq and he later snuck back into Jordan. See also Sassoon, The Iraqi Refugee Crisis; Fafo, Iraqis in Jordan.

52. Crisp, Janz, and Riera, Surviving in the City.

53. Women's Commission, Iraqi Refugees in Jordan.

54. Sassoon, The Iraqi Refugee Crisis.

55. Ibid.

56. International Organization for Migration statistics state that in 2008, there were 1,370 Iraqis who voluntary repatriated, 266 of whom received assistance from UNHCR. IOM, "Table 5. Refugees and people in refugee-like situation, excluding asylum-seekers, and changes by major origin and country of asylum, 2008," 2009. It is likely that a number of those counted in this statistic only returned temporarily as some Iraqis return to check on the situation, meet with family members, or do business.

57. Crisp, Janz, Riera, Surviving in the City.

58. International Rescue Committee, Iraqi Refugees in the United States: In Dire Straits, 2009, accessed October 26, 2010, http://www.theirc.org/sites/default/files/resource-file /irc_report_iraqcommission.pdf.

59. UNHCR, Resettlement Handbook (country chapters last updated September 2009) (Geneva, 2004), Ch.6, p. 3, accessed April 21, 2010, http://www.unhcr.org/refworld /docid/3ae6b35e0.html.

60. Ibid.

61. UNHCR, Resettlement Handbook, Ch. 8, p. 24.

62. Such insights emerged through informal interviews with representatives of UNHCR, various state embassies, and other international organizations during the collection of data for this study. In addition, see Ingrid Boccardi, Europe and Refugees: Toward an EU Asylum Policy (The Hague: Kluwer Law International, 2002), 43-44, for a discussion on the EU's efforts to halt "asylum shopping." See also Ann Maymann, "Challenges of Temporary Protection in Syria," Forced Migration Review 23 (2005): 42-43.

63. UN News Agency, "Syria assures UN it will not forcibly deport Iraqi refugees under new visa system" (September 4, 2007), accessed October 4, 2010, http://www.un.org/apps /news/story.asp?NewsID=23683\&Cr=Iraq\&Cr1.

64. UNHCR, Resettlement Handbook, Ch. 6, p. 13.

65. Hyndman, Managing Displacement.

66. Charles Hale, ed., Engaging Contradictions: Theory, Politics, and Methods of Activist Scholarship (Berkeley, CA: University of California Press, 2008); Karen Jacobsen and Loren B. Landau, "The Dual Imperative in Refugee Research: Some Methodological and Ethical Considerations in Social Science Research on Forced Migration," Disasters 3 (2003): 185-206; Peter Reason and Hilary Bradbury, eds. Handbook 
of Action Research: Participative Inquiry and Practice (London: Sage, 2001).

67. Chatelard, Protection has noted that those Iraqis who migrate to Jordan are predominantly secular and because inquiring about this topic was deemed too politically sensitive at the time of the study.

68. Fafo, Iraqis in Jordan, 10; see also Sassoon, The Iraqi Refugee Crisis.

69. One might argue that while Baqa'a is technically a refugee camp, it is also an intensely urban environment.

70. Kathy Charmaz, "Grounded Theory: Objectivist and Constructivist Methods," in Handbook of Qualitative Research, $2^{\text {nd }}$ ed., ed. Norm K. Denzin and Yvonne S. Lincoln (Thousand Oaks, CA: Sage Publications, 2000); Kathy Charmaz, "Grounded Theory," in Approaches to Qualitative Research, ed. Sharlene N. Hesse-Biber and Patricia Leavy (New York: Oxford University Press, 2004), 496-521.

71. Norm K. Denzin, Interpretive Interactionism (Newbury Park, CA: Sage, 1989); Amedeo Giorgi, "Phenomenological Psychology," in Rethinking Psychology, ed. Jonathan A. Smith, Rom Harre, and Luk van Langenhove (London: Sage, 1995), 24-42.

72. Charmaz, "Grounded Theory."

73. Because I locate respondents' thematic codes within a model of vulnerability provided by academic literature, this part of the analysis represents a more objectivist take on grounded theory, a version particularly found in such works as: Anselm Strauss and Juliet Corbin, Basics of Qualitative Research: Techniques and Procedures for Developing Grounded Theory, 3rd ed. (Thousand Oaks, CA: Sage Publications, 2008).
74. In particular, there are important class differences between Iraqis displaced in Jordan and it is likely that those with greater financial means are less likely to visit NGOs for humanitarian assistance.

75. Chatelard, "Jordan as a Transit Country"; Chatelard, Protection.

76. West and Wambugu, Left to Their Own Devices.

77. M. B. Lykes, "No Easy Road to Freedom: Engendering and Enculturing Forced Migration," in Driven from Home: Protecting the Rights of Forced Migrants, ed. David Hollenbach (Washington, D.C.: Georgetown University Press, 2009); Shana Swiss and Joan E. Giller, "Rape as a Crime of War," Journal of the American Medical Association 5 (1993): 612-15.

78. Roula Nasrallah and Kate Washington, "Iraqi Women Refugees in Syria: Impact of Protracted Stay in Asylum and Protection Concerns" (International Catholic Migration Commission, unpublished, 2009, on file with author).

79. Van Hear, "Refugees in Diaspora," 12. This paper's conclusion echoes in some ways Van Hear's suggests making transnational networks a focal point in UNHCR's search for permanent solutions.

80. Ibid., 14 .

Adam Saltsman is a PhD candidate in the Department of Sociology, Boston College. His interests include displacement and social capital, migration and capitalism, and participatory action research.

(C) Adam Saltsman, 2011. This open-access work is licensed under a Creative Commons Attribution-NonCommercial 4.0 International License, which permits use, reproduction and distribution in any medium for non-commercial purposes, provided the original author(s) are credited and the original publication in Refuge: Canada's Journal on Refugees is cited. 